\title{
BIOLOGY OF Anicla infecta (OCHSENHEIMER, 1816) (LEPIDOPTERA, NOCTUIDAE, NOCTUINAE), UNDER LABORATORY CONDITIONS
}

\author{
TESTON, J. A., ${ }^{1}$ SPECHT, A. ${ }^{1,2}$ and CORSEUIL, E. ${ }^{1}$ \\ ${ }^{1}$ Programa de Pós-graduação em Biociências, Área de Zoologia, PUCRS, C.P. 1429, CEP 90619-900, Porto Alegre, \\ RS, Brazil \\ ${ }^{2}$ Curso de Agronomia, Unisul, C.P. 370, CEP 88704-900, Tubarão, SC, Brazil \\ Correspondence to: José Augusto Teston, Faculdade de Biociências, PUCRS, Laboratório de Entomologia, \\ Av. Ipiranga, 6681, C.P. 1429, CEP 90619-900, Porto Alegre, RS, Brazil, e-mail: jateston@ pucrs.br \\ Received June 20, 2000 - Accepted August 28, 2000 - Distributed November 30, 2001
}

(With 1 figure)

\begin{abstract}
Larvae of Anicla infecta (Ochsenheimer, 1816) (Noctuidae) feed upon many grasses and may be harmful to cereals and fodder of economic importance. This study was developed aiming to contribute to knowledge of the biology of this species. The rearing was done in an environmental chamber with the following settings: temperature of $25 \pm 1{ }^{\circ} \mathrm{C}$; relative humidity of $70 \% \pm 10 \%$, and photoperiod of L14: D10. The larvae fed on ryegrass, Lolium multiflorum Lam. The results express the mean and standard error for the length of every stage in days. For each stage we observed the following time of development: egg $3.2 \pm 0.09$; larvae $18.7 \pm 0.07$; pre-pupae $3.3 \pm 0.04$; pupae $12.6 \pm 0.14$; and adult longevity was $12.1 \pm 1.03$. Also the pre-egg-laying period was $4.4 \pm 0.59$; the egg-laying period was $8.1 \pm 0.84$; and the post-egg-laying period was $0.3 \pm 0.14$. The mean number of egg-laying cycles per female was $6.7 \pm 0.73$; that of eggs per cycle was $77.5 \pm 4.37$; and total eggs per female was $521.4 \pm 47.36$.
\end{abstract}

Key words: development, Insecta, Lolium multiflorum, ryegrass.

\section{RESUMO}

\section{Biologia de Anicla infecta (Ochsenheimer, 1816) (Lepidoptera, Noctuidae, Noctuinae), sob condições de laboratório}

As lagartas de Anicla infecta (Ochsenheimer, 1816) alimentam-se de gramíneas, podendo tornar-se nocivas a cereais e forrageiras de importância econômica. A fim de contribuir com informações para o conhecimento de sua biologia, foi realizado um experimento com criação em câmara climatizada a $25 \pm 1^{\circ} \mathrm{C} ; 70 \% \pm 10 \%$ UR (umidade relativa) e fotofase de $14 \mathrm{~h}$. As larvas foram alimentadas com azevém, Lolium multiflorum Lam. Os resultados expressos pela média e pelo respectivo erro-padrão para os períodos de cada fase, em dias, foram: ovo 3,2 $\pm 0,09$; lagarta 18,7 $\pm 0,07$; pré-pupa 3,3 \pm 0,04 ; pupa $12,6 \pm 0,14$; e adulta: longevidade $12,1 \pm 1,03$, pré-oviposição $4,4 \pm 0,59$, oviposição $8,1 \pm$ 0,84 e pós-oviposição $0,3 \pm 0,14$. O número médio de posturas por fêmea foi $6,7 \pm 0,73$, ovos por postura, 77,5 $\pm 4,37$ e ovos por fêmea, $521,4 \pm 47,36$.

Palavras-chave: azevém, desenvolvimento, Insecta, Lolium multiflorum.

\section{INTRODUCTION}

The larval stage of most Noctuinae (= Agrotinae) is characterized by underground habits, vora- cious feeding, and use of several host plants (Scoble, 1995). Larvae of Anicla Grote, 1874, however, do not rest on the ground but on their host plants which are mainly grasses. 
Anicla infecta (Ochsenheimer, 1816) was originally described for Europe (Poole, 1989), but it also occurs throughout the Americas (Crumb, 1956). The larvae feed on several native and cultivated plants, including potatoes, onions, and especially grasses (Biezanko \& Bertholdi, 1951; Crumb, 1956; Biezanko et al., 1974). This species has been listed in inventories of economically important insects, along with key-pests (Silva et al., 1968; Biezanko et al., 1974; Corseuil \& Cruz, 1975). Between 1972 and 1975, A. infecta was represented in $98.6 \%$ and $69.4 \%$ of monthly samples using light traps in Jaboticabal and Piracicaba, SP, respectively (Lara et al., 1977). In Santa Maria, RS, between March 1971 and February 1973 it was present in 65\% of the samples (Link, 1977). Its wide geographic distribution and broad morphological variation both in the adult (Köhler, 1945) and larval stages (Crumb, 1956) explain the large number of synonyms known for this species.

The continuous practice of extensive monoculture of cereals and fodder often increase insect population growth to pest level. The efficient management of this problem requires biological understanding of the organisms that integrate these agrosystems at the population and community levels. Recent studies on $A$. infecta include sampling of specimens using light traps in Rio Grande do Sul (Carvalho et al., 1971; Tarragó et al., 1975; Link, 1977; Specht, 1996), ecological estimates of noctuid communities in São Paulo (Lara \& Silveira Neto, 1977; Lara et al., 1977; Silveira Neto et al., 1977), and descriptions of early stages plus new distribution records for Chile and Ecuador (Angulo \& Olivares, 1997). The study by Foerster \& Mello (1996) investigated the biology of this species [cited as " $A$. infecta (Guenée)" sic]. The author's suggestion that larvae of $A$. infecta are similar in size to those of Pseudaletia sequax Franclemont, 1951 raised the question of whether the material studied by Foerster and Mello had been properly identified. Examination of the voucher specimens in the Foerster collection confirmed our suspicion and revealed that the species studied by Foerster \& Mello (1996) was in fact $A$. ignicans (Guenée, 1852).

Our study aims to elucidate the biology of A. infecta. In the laboratory, we measured several aspects of its adult (e.g., longevity and fecundity) and larval biology (e.g., number and duration of each instar). Our findings broaden previous knowledge of the genus Anicla in particular, and contribute to the understanding of the biology of grass-associated insects in general

\section{MATERIAL AND METHODS}

Our study is based on 11 mating pairs from stock maintained in an environmental chamber at $25 \pm 1^{\circ} \mathrm{C} ; 70 \% \pm 10 \%$ humidity and $14 \mathrm{~h}$ of photophase; and the progeny that was obtained from these pairs. The methodology for studying adults and eggs followed Melo \& Parra (1988). The stock originated from Salvador do Sul, RS.

For the purpose of our research, the life cycle was divided into adult, egg, larval, pre-pupal, and pupal phases. In the adult phase we examined longevity, oviposition period (including pre and post-oviposition), number of oviposition events, total number of eggs, and the average number of eggs per oviposition event and per individual. The pre-oviposition period is equivalent to the number of days required for females to start laying eggs following eclosion and mating, and the post-oviposition period refers to the number of days they survive after oviposition has terminated. The mean values of the adult longevity and pupal dimension were compared through a $t$ test $(\mathrm{p}=0.05)$. The correlation between pupal length and width was calculated using the Pearson correlation coefficient.

For the study of immature stages, groups of larvae were placed in plastic containers $(12 \mathrm{~cm}$ diameter by $20 \mathrm{~cm}$ height) covered with a nylon screen. The host plant, ryegrass (Lolium multiflorum Lam.), was provided ad libitum and changed daily. The number of days required for the completion of each phase of development was recorded. To identify and count the number of larval instars, a control group was used from which 10 caterpillars were daily killed in boiling water and preserved in ethyl alcohol $70 \%$. Head capsules of preserved caterpillars were measured under a stereo microscope provided with an ocular micrometer, and the measures corresponding to different larval instars were grouped by frequency distribution (Parra \& Haddad, 1989). We estimated the duration of the larval period taking into account two separate phases; that in which the insects are actively feeding (hereafter called larval phase), and the pre-pupal phase. 
By definition, the pre-pupal phase begins when the larva stops feeding, and ends with pupation (Parra, 1992). During this phase; larvae were maintained on a piece of moist filter paper in a plastic container (10 $\mathrm{cm}$ diameter by $7 \mathrm{~cm}$ height) covered with a nylon screen.

Pupae were kept in a plastic container (14 $\mathrm{cm}$ diameter by $10 \mathrm{~cm}$ height), and following sex determination (Butt \& Cantu, 1962), we measured pupal length and width using digital calipers with a precision of one hundredth of a millimeter. We used a Chi-square test $\left(\chi^{2}\right)(\mathrm{p}=0.05)$ to test for deviations of the $1: 1$ sex ratio.

Six adult males and five females voucher specimens were deposited in the collection of the Museu de Ciências e Tecnologia of the Pontifícia Universidade Católica do Rio Grande do Sul (PUCRS), reference numbers MCTP 7566 and 7567, respectively.

\section{RESULTS AND DISCUSSION}

The mean duration of each phase of development of $A$. infecta is presented in Table 1, and the proportions (\%) are illustrated in Fig. 1. The complete life cycle of $A$. infecta was 49.9 days, of which 3.2 days were required for egg development, 18.7 for larval, 3.3 for pre-pupal, and 12.6 days for pupal development. The pre-pupal phase is a particularly delicate period of development in which larvae remain motionless in the soil and their cuticle is less resistant than that of pupae, yet 3.3 days are needed for the completion of this phase of development. The egg, larval, and pupal phases of $A$. infecta were slightly shorter than those of A. ignicans kept at $26^{\circ} \mathrm{C}$ (egg: 4 days; larva including pre-pupa: 24.4 days; and pupa: 15.4 days, as reported in Foerster \& Mello, 1996).

The mean duration of the adult phase was 11.4 days for males and 12.8 for females, and the difference between these values was not statistically significant (Table $1 ; t=0.96$ ). Eight of 11 studied females died soon after their last oviposition, and the other three died one day after the event. The mean number of oviposition events per female was 6.7, and each female laid on average 521.4 eggs, resulting in 77.5 eggs per oviposition event.

A comparison between our results for $A$. infecta and those of Foerster \& Mello (1996) for $A$. ignicans (as $A$. infecta, see Introduction) allowed us to verify whether these two species had similar biological characteristics. Anicla ignicans was reared on ryegrass at $22^{\circ} \mathrm{C}$ and $12 \mathrm{~h}$ photophase; and female longevity, oviposition period, and the duration of the egg, larval, (including pre-pupal) and pupal phases were recorded (Foerster \& Mello, 1996). The correlation coefficient corresponding to the two sets of parameters for the two species was $\mathrm{r}=0.96$ indicating that $A$. infecta and $A$. ignicans have similar developmental characteristics despite the differences in the temperature regime between our study and that of Foerster \& Mello (1996).

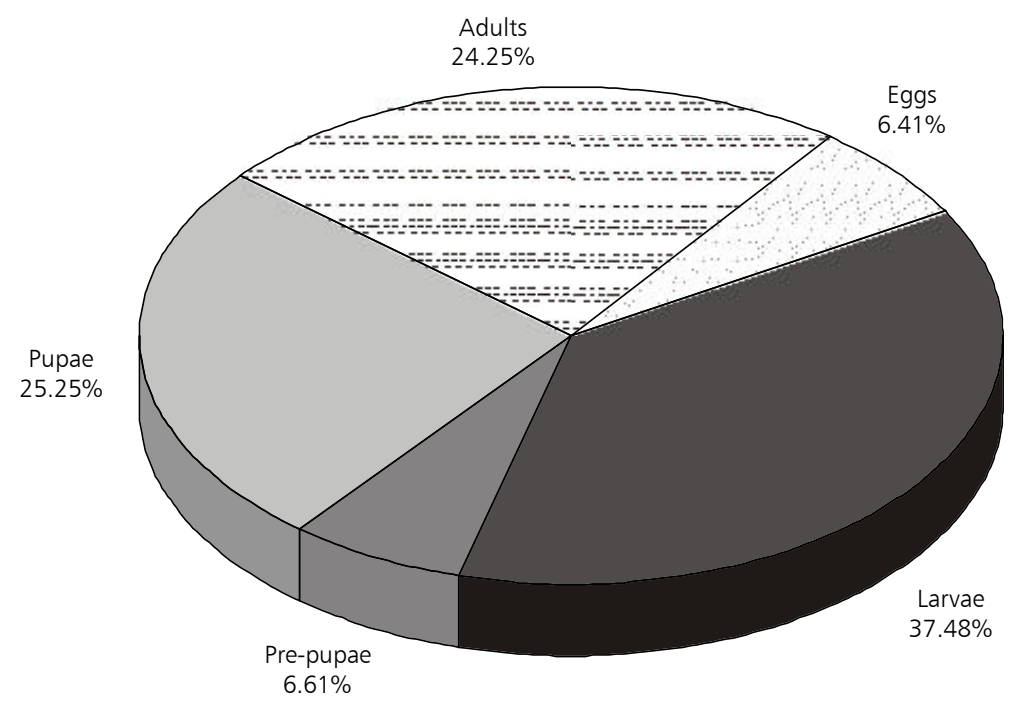

Fig. 1 - Percent of development periods for Anicla infecta reared at $25 \pm 1^{\circ} \mathrm{C}$, UR $70 \% \pm 10 \%$ and 14 h photophase. 
We recorded the mortality rate for $A$. infecta eggs and larvae, including the pre-pupal phase. In the laboratory, egg mortality was $13.2 \%$, i.e., 3,347 larvae eclosed from 3,652 eggs. Of 472 larvae studied, 211 reached the pre-pupal phase and 78 pupae were obtained. The high mortality rate in the larval phase is possibly due to the temperature at which the larvae were raised (ryegrass is a winter culture). Because A. infecta pupates in the soil, high mortality in the pre-pupal phase may reflect our inability to reproduce required conditions for pupation (e.g., appropriate humidity level).

Mean widths of head capsules of 210 larvae are presented in Table 2. The larval period of $A$. infecta was constituted of six instars, and the growth rate of $1.53 \%$ follows the rule of geometric growth (Dyar, 1890).

Head capsules of $A$. infecta were slightly smaller than those of A. ignicans studied by Foerster \& Mello (1996), but the growth rate was similar between the two species.

Pupal length and width are in Table 3. Males were significantly larger than females. The correlation between pupal length and width was 0.84 for female and 0.91 for male, suggesting that allometric proportions are maintained in pupae of different sizes.

The obtained sex ratio was 0.41 , which does not differ significantly from a $1: 1$ ratio $\left(\chi^{2}=1.6\right.$, $\mathrm{p}<0.05)$.

TABLE 1

Mean duration and standard error in days of development phases of Anicla infecta reared at $25 \pm 1^{\circ} \mathrm{C}$, UR $70 \% \pm 10 \%$ and 14 h photophase.

\begin{tabular}{|l|c|c|}
\hline \multicolumn{2}{|c|}{ Phases } & n \\
\hline Adult & 11 & Mean \\
\hline Male & 11 & $11.4 \pm 1.15$ \\
\hline Female (total) & & $12.8 \pm 0.91$ \\
\hline Pre-oviposition & & $4.4 \pm 0.59$ \\
\hline Oviposition & & $8.1 \pm 0.84$ \\
\hline Post-oviposition & 29 & $0.3 \pm 0.14$ \\
\hline Egg (incubate/laying) & 472 & $3.2 \pm 0.09$ \\
\hline Parval & 211 & $18.7 \pm 0.07$ \\
\hline Pre-pupal & 78 & $3.3 \pm 0.04$ \\
\hline
\end{tabular}

TABLE 2

Mean width and standard error in mm of cephalic capsules of Anicla infecta reared at $25 \pm 1^{\circ} \mathrm{C}$, UR $70 \% \pm 10 \%$ and $14 \mathrm{~h}$ photophase.

\begin{tabular}{|c|c|c|}
\hline Instars & $\mathbf{n}$ & Mean \\
\hline $1^{\circ}$ & 31 & $0.3 \pm 0.002$ \\
\hline $2^{\circ}$ & 19 & $0.5 \pm 0.002$ \\
\hline $3^{\circ}$ & 20 & $0.8 \pm 0.011$ \\
\hline $4^{\circ}$ & 33 & $1.3 \pm 0.017$ \\
\hline $5^{\circ}$ & 41 & $2.0 \pm 0.017$ \\
\hline $6^{\circ}$ & 66 & $2.9 \pm 0.017$ \\
\hline
\end{tabular}


TABLE 3

Mean and standard error of length and width, correlation coefficient and $t$ test of measures of the pupae of Anicla infecta reared at $25 \pm 1^{\circ} \mathrm{C}$, UR $70 \% \pm 10 \%$ and $14 \mathrm{~h}$ photophase.

\begin{tabular}{|l|c|c|c|c|}
\hline \multicolumn{1}{|c|}{ Pupae } & n & Length & Width & r \\
\hline Females & 32 & $12.2 \pm 0.15$ & $4.5 \pm 0.05$ & 0.84 \\
\hline Males & 46 & $13.0 \pm 0.15$ & $4.6 \pm 0.05$ & 0.91 \\
\hline$t(\mathrm{p}=0.05)$ & & 3.57 & 2.13 & \\
\hline
\end{tabular}

\section{CONCLUSION}

This study addresses the complete life cycle of $A$. infecta, including adult longevity and fecundity, time of development for all life stages, and measurements of body size for caterpillars and pupae. We found that the previously published description of the life cycle of $A$. infecta (Foerster \& Mello, 1996) actually refers to A. ignicans. A comparison of our results with those obtained by Foerster \& Mello (1996) for A. ignicans indicated that the two species have similar developmental characteristics.

Anicla infecta is a polyphagous species that has high morphological variation, and is widely distributed in the Americas, occurring with accessory species in different crops. The present study explores important biological characteristics of this species, and will be useful for future comparison with other noctuid species.

Acknowledgments - We thanks Ph.D., Carla M. Penz, for careful translation, suggestions, and review of the manuscript.

\section{REFERENCES}

ANGULO, A. O. \& OLIVARES, T. S., 1997, Anicla infecta (Ochsenheimer, 1816): pupa, larva y nuevo registro (Lepidoptera, Noctuidae). Bol. Soc. Biol. Concepción, 68: 47-52.

BIEZANKO, C. M. de \& BERTHOLDI, R. E., 1951, Principais noctuídeos prejudiciais às plantas cultivadas em arredores de Pelotas. Agronomia, 10(4): 235-247.

BIEZANKO, C. M. de, RUFFINELLI, A. \& LINK, D., 1974, Plantas y otras sustancias alimenticias de las orugas de los lepidopteros uruguayos. Rev. Centro Ciências Rurais, Santa Maria, 4(2): 107-148.

BUTT, B. A. \& CANTU, E., 1962, Sex determination of lepidopterous pupae. USDA, Washington, $7 \mathrm{p}$.
CARVALHO, S., TARRAGÓ, M. F. S. \& LINK, D., 1971, Captura de noctuídeos através de armadilha luminosa. I - Resultados preliminares. Rev. Centro Ciências Rurais, Santa Maria, 1(3): 15-22.

CORSEUIL, E. \& CRUZ, F. Z. da, 1975, Insetos nocivos à cultura do trigo no Rio Grande do Sul. Rev. Faculdade Agronomia UFRGS, Porto Alegre, 1(1): 19-28.

CRUMB, S. E., 1956, The larvae of the Phalaenidae. Technical Bulletin n.1135, USDA, Washington, 356p.

DYAR, H. G., 1890, The number of molts of lepidopterous larvae. Psyche, Berlin, 5: 420-422.

FOERSTER, L. A. \& MELlO, M. E. F., 1996, Desenvolvimento e sobrevivência de Anicla infecta Guenée (Lepidoptera: Noctuidae) em diferentes temperaturas. Anais Soc. Entomol. Brasil, Piracicaba, 25(1): 33-38.

KÖHLER, P. E., 1945, Los «Noctuidae» argentinos. Subfamilia Agrotinae. Acta Zool. Lilloana, Tucumán, 3 : 59-134.

LARA, F. M. \& SILVEIRA NETO, S., 1977, Flutuações populacionais de noctuídeos pragas, na região de Jaboticabal, SP. Científica, Jaboticabal, 5(3): 262-270.

LARA, F. M., SILVEIRA NETO, S. \& FORTI, L. C., 1977, Constância e diversidade de espécies de noctuídeos coletados em Jaboticabal e Piracicaba com auxílio de armadilhas luminosas. Científica, Jaboticabal, 5(2): 144-151.

LINK, D., 1977, Abundância relativa de alguns Noctuidae, em armadilha luminosa, em Santa Maria, RS. Rev. Centro Ciências Rurais, Santa Maria, 7(4): 331-351.

MELO, A. B. de P. \& PARRA, J. R. P., 1988, Biologia de Diatraea saccharalis em diferentes temperaturas. Pesq. Agropec. Bras., Brasília, 23(7): 663-680.

PARRA, J. R. P., 1992, Técnicas de criação de insetos para programas de controle biológico. FEALQ, Piracicaba, $161 \mathrm{p}$.

PARRA, J. R. P. \& HADDAD, M. de L., 1989, Determinação do Número de Ínstares de Insetos. FEALQ, Piracicaba, 49p.

POOLE, R. W., 1989, Noctuidae. In: J. B. Heppner (ed.), Lepidopterorum Catalogus. Brill, New York, 1314p.

SCOBLE, M. J., 1995, The Lepidoptera: form, function and diversity. Oxford University Press, New York, 404p. 
SILVA, A. G. A., GONÇALVES, C. R., GALVÃO, D. M., GONÇALVES, A. J. L., GOMES, J., SILVA, N. M. \& SIMONI, L., 1968, Quarto catálogo dos insetos que vivem nas plantas do Brasil, seus parasitos e predadores. Parte 2, Tomo 1. Min. Agricultura, Rio de Janeiro, 622p.

SILVEIRA NETO, S., LARA, F. M. \& FAZOLIN, M., 1977, Quociente e porcentagem de similaridade entre as comunidades de noctuídeos amostradas em Jaboticabal e Piracicaba, SP. Científica, Jaboticabal, 5(3): 257-261.
SPECHT, A., 1996, Dinâmica populacional de noctuídeos (Lepidoptera: Noctuidae) e inimigos naturais, em lavouras de azevém e milheto, no município de Salvador do Sul, RS, Brasil. MSc. Thesis, PUCRS, Porto Alegre, 85p.

TARRAGÓ, M. F. S., CARVALHO, S. \& LINK, D., 1975, Levantamento da família Noctuidae através de armadilhas luminosas, em Santa Maria, RS. Rev. Centro Ciências Rurais, Santa Maria, 5(2): 125-130. 